\title{
UMA ANTROPOLOGIA VIVA: Entrevista com Claudia Fonseca
}

\author{
A LIVE ANTHROPOLOGY: \\ Interview with Claudia Fonseca
}
Entrevistadores: Flávia Ferreira Pires * Marcia Longhi**
Pedro Nascimento ${ }^{* * *}$

Transcrição: Patrícia Santana S. de Oliveira

\begin{abstract}
Claudia Lee Williams Fonseca nasceu em Boston, no Estado de Massachusetts. Possui graduação em Letras pela University of Kansas (1967) e mestrado em Estudos Orientais pela mesma universidade (1969). Desenvolveu seu primeiro doutorado em Sociologia pela Ecole des Hautes Etudes en Sciences Sociales (1981) e, posteriormente, doutorado em Ethnologie, pela Université de Nanterre (1993). É professora na UFRGS desde 1978, onde atuou como professora no Departamento de Antropologia e atualmente é professora permanente no Programa de Pós-Graduação em Antropologia Social.
\end{abstract}

Em uma manhã ensolarada e quente, entrecortada por rajadas de vento e chuva, típicos do inverno de João Pessoa, tivemos o prazer da companhia de Claudia Fonseca. Aproveitando sua estadia na nossa cidade, para participar da $30^{\mathrm{a}}$ Reunião da Antropologia Brasileira, em agosto de 2016, conseguimos entrevistá-la. Apresentamos aqui alguns momentos dessa revigorante conversa que nos deixou a todos, professores da Universidade Federal da Paraíba, com energia para enfrentar o cotidiano e as adversidades da vida de professores e pesquisadores.

\footnotetext{
* Doutora em Antropologia Social pelo Museu Nacional, Universidade Federal do Rio de Janeiro (MN/ UFRJ); professora do Programa de Pós-graduação em Antropologia da Universidade Federal da Paraíba (PPGA/UFPB), Brasil. E-mail: ffp23279@gmail.com

** Doutora em Antropologia Social pela Universidade Federal de Pernambuco (UFPE); professora do PPGA/ UFPB, Brasil. E-mail: marciareislonghi@gmail.com

*** Doutor em Antropologia Social pela Universidade Federal do Rio Grande do Sul (UFRGS); professor do PPGA/UFPB, Brasil. E-mail: pedroparaiba@gmail.com
} 
Pesquisadora de relevo na antropologia brasileira, Claudia Fonseca é autora de dezenas de artigos e livros muitos célebres e referências essenciais para o estudo de parentesco, família e infância. Sua trajetória demonstra uma vivacidade incomum, um apego ao trabalho de campo e aos dados empíricos típicos da antropologia norteamericana, que ela aprimorou nas suas pesquisas em terras brasileiras. Sem nenhuma arrogância, sempre pesquisando, mesmo já aposentada na Universidade Federal do Ro Grande do Sul (UFRGS), Claudia nos presenteou com conselhos sábios e sua visão de mundo alargada pela experiência e pela empatia para com o que é humano.

\section{Claudia menina, mãe, mulher}

Flávia Pires: Eu queria que você me falasse um pouco sobre a menina Claudia.

Claudia Fonseca: A menina Claudia faz muito tempo... Sou filha de militar; morei na Inglaterra e no Marrocos. Lembro, no Marrocos, daquela sensação de não poder sair da base, visitar amigos do lugar, a casa de nosso empregado doméstico, por exemplo. Foi o momento de separação do Marrocos da França. Havia muito conflito político e eu tinha seis anos, entendeu? Lembro que marcou muito a minha mãe também não era exatamente a rotina à qual estava acostumada como dona de casa do Centrooeste dos Estados Unidos. Mas, bom, eu me pergunto às vezes se tem alguma coisa a ver com a minha vontade de conhecer coisas e lugares diferentes.

Depois meu pai morreu, eu tinha então oito anos, e minha mãe "teve que trabalhar". Começou uma carreira de professora - primeiro na escola primária, depois secundária, depois na universidade. Aí, meu irmão (quatro anos mais velho) e eu tomamos conta da casa. Durante todo esse tempo, meu mundo era absolutamente classe média americana. A década de 1960 foi uma época fecunda: começou com a revolução social, incluindo a chamada liberação da mulher e a ideia de que "meu corpo me pertence", e se estendeu para a política, para a guerra do Vietnã. Foi uma época de grande contestação, em que os jovens não ficavam quietos. Eu não me considerava líder, de forma alguma, mas desfrutei desse ambiente iconoclasta - de não aceitar as coisas, as verdades consagradas. Além disso, tive uma boa formação escolar, sempre em escolas públicas. Já na faculdade, ganhei bolsas para viajar: fiz um ano de faculdade em Bordeaux, no sistema francês, e quase um ano em Formosa (China Nacionalista) e, é claro, aqueles verões de pesquisa etnográfica na Micronésia. Bom, tudo isso faz parte da minha formação.

Marcia Longhi: Eu fiquei curiosa, talvez tenha a ver com a minha trajetória de vida, na entrevista que você deu em Natal, que está no Youtube, no site da $A B A^{2}$, você falou muitas coisas, mas me lembro de, em algum momento, naquela entrevista, você ter dito que, quando estava na França, sentia-se um pouco decepcionada com a vida acadêmica, fazendo outras coisas, e neste momento você engravidou. Eu queria ouvir um pouco sobre essa Claudia mãe e também de que forma isso impactou sua vida naquele momento.

2 Disponível em: <https://www.youtube.com/watch?v=L46-mYw4wRE>. 
Claudia Fonseca: Pois é, quando caí fora do programa de doutorado da Universidade de Columbia, resolvi voltar para França, dessa vez para viver. Naquela fase de minha vida - de imigrante indocumentada, vivendo de biscates, aprendi a ter um apreço tremendo pela presença estatal na minha vida. (Todos: Risos) Era o auge do Estado de bem estar social. Nem eu, nem José (meu marido) tínhamos família lá, apenas alguns amigos. Não tínhamos nem casa onde morar, estávamos vivendo de subaluguel, tendo que mudar a cada mês. E eu fiquei grávida. Aí foi aquela coisa, como que a gente lida com isso? Foi a rede de serviço social que me ensinou que eu tinha direitos. Fui acolhida por um serviço público. Eles tinham toda uma política de incentivo de natalidade. Estar grávida na França, naquela época, era um barato. Todo mundo me tratava muito bem. Era uma coisa encantada, e me integrou dentro da sociedade francesa como nenhuma outra experiência poderia ter feito. Se não fosse a maternidade, eu teria sempre ficado um pouco na margem. Fui conhecer o sistema de creches, escolas maternais e todo o resto. Foi uma experiência positiva que me levou a dar valor a uma presença positiva do Estado. A gente se virava economicamente com bicos, dando aula de língua. Claro, reconheço que eu tinha a vantagem de ser uma pessoa branca, com capital simbólico e cultural - a língua inglesa e um diploma universitário. Mas isso nunca me ajudou a regularizar minha situação. Vim embora depois de sete anos, ainda sem carteira oficial de residência.

Mas, essa coisa de ser mãe, o que a gente sabia? Nada, nem como trocar uma fralda. Sabe? Quando voltei do hospital com meu primeiro filho e tivemos que lidar com aqueles cuidados rotineiros de um recém-nascido, José olhou para mim e disse: "Mas tu é mulher. Deve saber dessas coisas"... [risos] O problema é que na família americana não temos esta socialização de como lidar com crianças. Não tem um montão de primos e sobrinhos morando perto para a gente ficar ensaiando. Aí, para mim, era tranquilizador poder frequentar os serviços de pediatria, fazer todos os controles que a cartilha mandava...

Sempre curti muito ser mãe. Nunca me senti amarrada. Tenho que dizer que meu marido também foi extremamente companheiro -- um pai coruja. Desde o início, ele sempre esteve muito presente. Agora, os meus filhos podem ter queixas da minha forma de ser mãe. Eu tive que aprender. É isso que eu digo, ser mãe pra mim valeu por três doutorados em termos do que eu aprendi na vida. Em termos do que eu aprendi a viver com a diferença. De respeitar. Pra mim, sabe, não é quando eles eram pequenos. Quando eles eram pequenos eu adorava a sabedoria deles, nós os tratávamos quase como pequenos adultos. Quando eles começaram a entrar naquela pré-adolescência é que fui me dar conta de como eles não iam mais onde eu dizia. Eles têm ideias próprias e estão se colocando, 'eu não estou de acordo', certo?!. Aí tu começas a ter que conviver com aquela diferença. E não são nada como tu imaginavas que os seus filhos seriam. Eles são eles. E pra mim isso foi uma lição que toda a antropologia do mundo não teria me trazido da mesma forma. Então, ser mãe é isso. Mas eu não posso falar mais porque eles odeiam que eu fale deles. [Todos: Risos]

Pedro Nascimento: Eu estava vendo recentemente no Facebook - não lembro de quem se estava falando, uma discussão sobre casos de mulheres antropólogas cujos maridos eram também antropólogos, de como as mulheres tinham que, às vezes, deixar de 
lado o seu trabalho de campo, a sua carreira, para cuidar das crianças, enquanto seus maridos continuavam. No seu caso eu vejo que, pelo que está dizendo, com a parceria do José, que não é acadêmico...

Claudia Fonseca: José é jornalista. Já trabalhou em todos os jornais da cidade (Porto Alegre). Também trabalhou para o governo Olívio Dutra, na equipe de jornalistas. Simultaneamente, trabalhava na imprensa alternativa, na área de ecologia, e continua atuando na área de ecologia e filosofia Zen. Mas, ao longo dos anos, sempre me deu um apoio extraordinário. Foi fundamental para minha carreira universitária. É poeta e escritor, e todos os meus primeiros textos passaram por ele. Os primeiros textos ele lia e dizia: 'Eu não estou entendendo nada. Para com esse antropologuês'. Corrigia o português também. Até hoje. O José é uma pessoa que não dá mole, que é muito franca comigo. Falamos que, depois de tantos anos, ele é antropólogo por osmose.

\section{Feminismo: sem medo de começar de novo}

Pedro Nascimento: Eu queria que você falasse um pouco sobre a tua relação com o feminismo de uma forma mais geral. Aproveitando o que você estava falando agora sobre o seu contexto lá na França: jovem, virando mãe etc. Mas no teu trabalho também o feminismo tem uma presença no diálogo com muitas antropólogas feministas, particularmente me chama atenção a sua discussão a partir da influência das novas tecnologias reprodutivas e como você se situa nessa relação.

Claudia Fonseca: Eu acho que o feminismo faz parte do meu DNA. Eu lucrei totalmente da primeira geração. Não esqueça que eu fui criada por uma mãe viúva, sozinha. Ela também era, ao seu modo, muito feminista. Então eu cresci ouvindo queixas dela sobre a discriminação ou assédio que sofria no trabalho por ser mulher. Minhas amigas de colégio eram - como eu diria? - não feministas organizadas, mas totalmente dedicadas à ideia da igualdade. Tudo o que os homens faziam, nós queríamos fazer também. Tínhamos orgulho de ser mulheres. As intimidades, as alianças, eram com nossas amigas, com as quais a gente pintava e bordava. Saía em bando no meio da noite, fazia arte, fazia muita coisa. Saíamos e namorávamos com os rapazes, mas não íamos nunca deixar um namoro interferir nas nossas alianças femininas. Por isso eu digo que da primeira geração eu lucrei demais (ver FONSECA, 2016).

Depois - no Alto Volta (África Ocidental) -- tive outra experiência de feminismo. Cheguei à África como assessora da Organização das Nações Unidas para a Educação, a Ciência e a Cultura (Unesco), onde trabalhei com Scholastique Kompaoré, a mulher "local" a quem eu devia ensinar o ofício de etnógrafo. Tinha uma grande ironia na ideia de que eu, com os meus 23 anos, sem experiência de ensino e totalmente estrangeira ao local, devia ensinar etnologia para Scholastique, mulher instruída, mãe de cinco filhos, e com uma vasta experiência nas realidades locais. Era, e continua sendo, uma pessoa extraordinária, assumidamente feminista (pouco tempo atrás, foi presidente da Marcha Mundial de Mulheres em BurkinaFasso). 
Ela me ensinou muito, entre outras coisas, sobre o rito de excisão feminina. Sobre isso, me dizia com grande firmeza: "Vocês, feministas brancas, não venham se meter nesses assuntos (de mulheres africanas). Não precisamos de sua compaixão." Tem que lembrar que o Alto Volta, recentemente, tinha ganhado sua independência da França. Scholastique era muito consciente de como a pretensa superioridade moral dos países ocidentais reforçava atitudes colonialistas; ela participava, junto de outros intelectuais do país, de um esforço para encontrar novos caminhos "africanos" para lidar com diferentes problemas. Aliás, ela mesma tinha passado pelo rito, mas se considerava uma mulher sexualmente realizada. Tinha uma relação muito forte com o marido. Ele cuidava dos cinco filhos na capital enquanto ela ficava conosco no interior ou, de outra forma, absorvida nas atividades profissionais. Anos depois, encontrei um texto de Scholastique onde conta com orgulho como -- conversando, costurando, debatendo, com seus conterrâneos e outros africanos, homens e mulheres - o movimento tinha levado o congresso nacional a proibir a excisão. Mas tudo ao modo delas, das feministas africanas.

Para mim, foi uma lição na pele de outro feminismo, dos anos 1980, do "feminismo da diferença". Comecei a questionar certas "verdades" do feminismo da minha juventude e, em particular, nossa ânsia de intervir para "salvar" mulheres oprimidas. A pergunta era: quando estamos sendo solidárias e quando estamos sendo (ironicamente) paternalistas, reforçando opressões colonialistas em nome de prioridades e modos de agir definidos unilateralmente? Aí tu te dá conta que, às vezes, tem que pôr tuas ansiedades entre parênteses para escutar, para respeitar a experiência acumulada das pessoas que estão ali vivendo certa realidade e em determinadas condições. Não tem nada a ver com relativismo "barato" - e tem tudo a ver com um engajamento político dialogado e reflexivo.

Ao longo dos anos 80, houve ainda outra virada do feminismo que sedimentou uma linha de análise à qual me associo. As pesquisadoras feministas dessa época eram pioneiras na desconstrução de verdades fixas, inclusive elaborando uma autocrítica de algumas de suas próprias produções anteriores. Aquele diálogo entre Gayle Rubin e Judith Butler (RUBIN; BUTLER, 2003) é um bom exemplo. Como devem saber, Gayle Rubin, nos anos 70, foi autora de um artigo que se tornou logo um clássico, usando a prostituição como símbolo por excelência da exploração das mulheres. Mas, com o tempo, através de diferentes experiências de vida, do debate com diferentes ativistas, inclusive profissionais do sexo, ela repensou seus argumentos e voltou atrás. Veio a perceber que a eficiência retórica do seu grande artigo se apoiava na estigmatização de uma categoria de mulheres trabalhadoras. Vendo assim, fez uma autocrítica fundamental: o "ganho retórico" de seus argumentos não justificava atitudes do senso comum que racionalizavam a perseguição aos trabalhadores do sexo.

Para mim, esse espírito é o cerne do pensamento feminista: não ter medo de admitir fragilidades e a necessidade de rever tuas convicções mais arraigadas. Foucault, aliás, tem uma citação linda dizendo exatamente isso - que aqueles pesquisadores que não 
sabem "se inquietar, começar e recomeçar, tentar, errar, retomar tudo de novo do início até o fim" não são do mesmo planeta que ele (FOUCAULT, 1984, p. 13). Não é só o fato de que estamos sempre tendo novas experiências que mudam nossa cabeça. A própria realidade muda a uma velocidade impressionante, fazendo com que certa análise que talvez coubesse no passado, hoje não faça mais sentido. Tem a ver com essa questão do engajamento político, que para mim é tão importante.

Alguém me perguntou, recentemente, por que pareço mudar frequentemente de tema de estudo; pelo menos, não fico com o mesmo universo empírico de pesquisa por muito tempo. Para responder, é importante frisar que admiro terrivelmente os pesquisadores que se engajam em longo prazo num movimento. Acumulam experiências e sofisticam suas análises, ao mesmo tempo em que levam adiante uma colaboração política consequente. Mas, no meu caso, tenho a impressão de que, se fico demais num assunto, começo a me repetir, e tenho medo disso. De que - um belo dia - aquilo que "descobri", construí como análise inovadora, corra o risco de ser um fato consumado. A “circulação das crianças", por exemplo, me parecia uma noção útil para entender a organização familiar em grupos populares de Porto Alegre durante os anos 80 e para oferecer uma alternativa a conceitos estigmatizantes como "famílias desestruturadas". Na época, a noção me trouxe fama de ser "expert" em temas como família e infância. Mas será que esse tipo de discussão continua relevante hoje, num contexto onde tem Bolsa Família, escolarização universal etc.? Quem sabe, tem questões novas bem mais importantes. Uma ideia que foi estimulante em determinado momento, em outro pode se tornar contraproducente acadêmica ou politicamente. A gente tem que se perguntar, sempre: em que lugar estamos hoje, como que estão as coisas aqui e agora?

Se fico muito tempo num mesmo campo, com um mesmo tema, sinto que arrisco perder essa cautela. Tenho medo de acabar pregando "verdades velhas". Isso seria trair o tipo de antropologia e de filosofia de pesquisa feminista que me levaram a estar onde estou. Agora, quero insistir, isso é uma coisa muito pessoal. Como diz Marilyn Strathern (1997), a abordagem analítica de qualquer pesquisador é resultado de escolhas políticas e estéticas; é algo altamente pessoal.

Contudo, há um outro lado dessa questão. Podemos considerar que, de certa forma, o pesquisador desenvolve uma obrigação de continuar engajado em alguns debates que suas pesquisas provocaram. A gente aspira produzir conhecimentos que podem ser relevantes para o mundo em que vivemos e, para isso, não basta se satisfazer com aquela sensação de "ah, eu descobri tal coisa, eu desconstruí aquele estereótipo (sobre mães solteiras, famílias desestruturadas, adoção por pais homossexuais, sei lá...), agora o mundo vai mudar". Tem que levar aquela ideia para frente com políticas e alianças com outros pesquisadores, pessoas de outras disciplinas e aliados fora do mundo acadêmico. É nessas alianças que a luta contra preconceitos do senso comum começa a fazer mais sentido - num esforço mais abrangente e de longo fôlego. Vocês sabem que há avanços e retrocessos nas discussões políticas. Não existe "conquista" irreversível; não tem um momento onde se pode dizer "já mostramos que 
esse preconceito não tem fundamento nenhum, então podemos passar para outros assuntos". Por isso, às vezes, é necessário repetir, sim, certas ideias, voltar a colocar argumentos ou evidências que, para ti, já parecem desprovidos de novidade, mas que, numa nova conjuntura, ficaram completamente ignorados.

Essas alianças abrangentes e de longo fôlego estão aparentes em muitos lugares da Antropologia brasileira. Tive o privilégio, nos últimos três anos, de participar de cinco bancas de professor titular de cinco grandes antropólogos: Russel Parry Scott, Carmem Silvia Rial, Antônio Carlos de Sousa Lima, Miriam Pillar Grossi e Luiz Fernando Dias Duarte. Já tinha familiaridade com a originalidade do pensamento de cada um desses pesquisadores, com a excelência de suas reflexões. Mas não tinha me dado conta o quanto essas pessoas estavam envolvidas nas diferentes arenas políticas, desde a liderança em assuntos de antropologia institucional, consolidando as condições para um trabalho profissional de qualidade, até o investimento no diálogo com diferentes setores da sociedade, na forma de incontáveis consultorias e parcerias, além dos cursos de extensão e especialização.

[Direcionando-se aos entrevistadores...] Vocês também estão envolvidos nesses esforços nas suas diferentes áreas, não é? Quer dizer, não só nos preocupamos em realizar pesquisas sólidas, também nos questionamos sobre a inserção dessas pesquisas no mundo. A questão é: através de quais colaborações e formas de divulgação? Como tornar essas pesquisas consequentes? Acho que os estudantes em início de carreira não têm ideia do trabalho que investimos nessa parte. Nós, orientadores, já ficamos contentes quando os estudantes conseguem fazer uma pesquisa original e bem fundamentada, mas quem garante que essa pesquisa não vai simplesmente ficar mofando na estante de alguma biblioteca? Aí que entra esse trabalho coletivo e de longo fôlego que nem sempre os estudantes reconhecem.

Flávia Pires: No nosso GT Antropologia da Infância você falou sobre como é importante fazermos alianças, em contraste com textos que focam na denúncia.

Claudia Fonseca: Acho necessário destacar a pluralidade dos estilos de engajamento. Acho que temos que ter coragem de experimentar com linguagens diferentes. Em alguns casos, pode caber uma linguagem que beira a denúncia, para deixar bem clara certa posição nossa. Mas não estou convencida de que seja sempre a melhor opção. A antropologia atua em muitos lugares e tem plateias variadas. Em alguns cenários, somos vistos como pessoas arrogantes, pessoas "do contra", que não têm nada de positivo para oferecer. O desafio é entrar no diálogo, mantendo nossa visão crítica, mas também privilegiando a escuta - não só a escuta, mas também a conversa -, mesmo com aquelas pessoas cujas ideias entram em colisão com as nossas.

Para explicar melhor, gostaria de evocar um belo texto de uma filósofa feminista, Maria Puig de la Bellacasa (2011), da área de Estudos da Ciência e Tecnologia. Ela fala na necessidade de uma ética "cuidadosa" de pesquisa, sem abrir mão de uma visão crítica. As duas coisas, entendeu? A parte "cuidadosa" é não ceder à denúncia fácil, não reproduzir análises simplistas em que o lado "certo" e o lado "errado" já 
parecem definidos de antemão. Tem muito a ver com Latour (2005) que, ao descrever a noção de epistemologia política, também levanta a necessidade de proceder com calma.

A coisa mágica da pesquisa de campo é que, com o olhar de etnógrafo, atento à complexidade de detalhes e lógicas alheias, a gente consegue evitar moralismos simplistas. As oposições radicais parecem se desmanchar no ar. Num debate acadêmico e nas conferências que dou, posso polemizar - tentando oferecer uma clara alternativa à lógica de algum colega ou autor. Mas, quando entro na pesquisa de campo, antes de criticar ou me opor, estou realmente querendo escutar a razão da outra pessoa. Que seja costureira ou administrador de empresas, estou pensando: essa pessoa é inteligente, mas não pensa igual a mim. Quero entender qual o raciocínio dela; talvez eu aprenda alguma coisa nova. Acho que é essa abertura, junto com a eterna dúvida e a possibilidade de mudar de postura que, para mim, significam uma ética "cuidadosa" de pesquisa.

Nunca vou esquecer quando a equipe do NACI foi convidada a analisar os abrigos da (então) Fundação Estadual para o Bem Estar do Menor - Febem (FONSECA; SCHUCH, 2009). O discurso da diretoria da instituição era de que o Estatuto da Criança e do Adolescente (ECA) estava trazendo tudo de bonito, maravilhoso -- uma nova maneira de lidar com os jovens. Se tudo não estava funcionando bem, é porque os antigos funcionários e monitores não estavam conseguindo se desvencilhar do "vício da cultura institucional". Parecia que todas essas pessoas, agindo com anos de experiência, eram o inimigo, e a esperança de salvação vinha apenas da nova turma, do novo governo, da mais recente campanha de moralização (naquele momento, concentrada no ECA). Nossa etnografia das práticas do dia a dia das alas das diferentes instituições atenuava em muito essa visão dicotômica das coisas. Trazia o registro de dimensões interessantes -- entendimentos diferentes, práticas inovadoras, e também problemas distintos daqueles previstos -, demonstrando que as diferentes categorias de funcionário não eram tão homogêneas. Aliás, devo mencionar que, entre os funcionários (nem muito novos, nem muito antigos), tínhamos interlocutoras que, subsequentemente, deixaram a instituição para assumir o papel de pesquisadoras: Patrice Schuch e Marta Jardim. Certamente, a escuta dessas e de outros "nativos" foi fundamental para a formulação (conteúdo e estilo) de nosso relatório final.

Lembro que, quando a equipe foi discutir o relatório com o pessoal da Febem, ficamos (claro) bem nervosos com as reações. Não sei se os dirigentes gostaram muito, mas tinha um monitor que estava lá há mais de duas décadas que comentou: “Eu li tudo e eu me vi em cada página desse relatório”. Sabe, fiquei muito contente, porque tínhamos tentado descrever honestamente o que observamos na instituição - sem denúncia fácil, sem bodes expiatórios, sem bandidos ou heróis. Os detalhes etnográficos ressaltam diferenças, não dicotomias; acabam com as oposições simplistas e, quem sabe, ajudam a construir pontes de comunicação. 


\section{Antropologia pública}

Flávia Pires: Tenho uma pergunta, uma questão mais pessoal mesmo, do ponto de vista da minha pesquisa. Os colegas me perdoem, mas queria um conselho sobre a área dos estudos da criança. A gente está em um impasse. Não sabemos se vale a pena perseguir uma ideia de antropologia da criança ou se vale mais a pena a gente se juntar com os outros campos como sociologia, educação, enfim. Se investimos nos estudos da infância, que é interdisciplinar por natureza, que é o caminho que foi feito na Inglaterra, ou se realmente vale a pena investir politicamente no campo da antropologia da criança. $O$ que, para os antropólogos e para as próprias crianças, é mais útil?

Claudia Fonseca: Em primeiro lugar, como eu te disse, fiquei muito impressionada com a demanda. É evidente a grande audiência e participação no GT Antropologia da Infância (organizado por Flávia Pires e Lévi Pereira durante a 30a Reunião da ABA). Não há dúvida de que esse tema tem amplo apelo. Agora, tem aquele problema que a gente está constantemente enfrentando que é desconstruir a própria ideia da infância. E aí parece que o próprio nome do grupo tende a reificar a noção. Na verdade, Flávia, o que não reifica? "Núcleo de Antropologia e Cidadania" também reifica a noção de cidadania... A gente está sempre procurando uma saída.

São as tensões que a gente vive, porque, por um lado, queremos ser teoricamente sofisticadas, e aí temos que inventar um vocabulário completamente novo para evitar todas as reificações do passado, mas, por outro, queremos ser politicamente consequentes - o que significa, em certos casos, falar uma linguagem que é entendida pelas pessoas com as quais queremos falar. Estou relendo um artigo de Fassin (2012), nesse momento, onde ele diz que não se importa muito em procurar a definição "certa" dos conceitos. O importante é refletir sobre as implicações e os limites de qualquer termo. Lembro tantos debates em que ficamos horas criticando tal palavra por ser politicamente incorreta, cobrando o uso de outro termo completamente "novo". Todo mundo sabe que esse novo termo não vai ser uma vara mágica, não vai necessariamente endireitar a situação, mas o que vale é a discussão, a crítica, a busca, a insatisfação - instrumentos que nos ajudam a entender a complexidade do tema.

Em termos da "infância", vocês estão constantemente remoendo esse termo e perguntando, explícita ou implicitamente, o que é essa infância? Como traçar uma linha demarcadora entre a infância e a vida adulta? Será que, ao usar esses termos, não estamos voltando para noções universais, sem qualquer contexto? Qual a produtividade dessa linha demarcadora para nossas pesquisas? São perguntas que devem ser feitas... que os antropólogos conhecem bem. As nossas dúvidas servem para desnaturalizar noções do senso comum que têm a ver com idade, gênero, saúde... praticamente tudo. Mas será que isso quer dizer que não podemos usar uma linguagem mais do dia a dia que seja inteligível para pessoas de fora da antropologia?

Essa questão tem a ver com a discussão sobre as plateias da etnografia proposta por Fassin (2013). Usamos muitas linguagens diferentes nos nossos textos escritos e palestras e, em cada nova situação, para encontrar a linguagem adequada, temos que colocar a pergunta: para que "público" nossa antropologia está sendo dirigida? Acho que, no fundo, temos que arcar com o fato de que não tem palavras, termos ou 
conceitos acima das armadilhas, e que nós estamos usando determinadas categorias porque, no momento, taticamente faz sentido.

\section{Antropologia e ciência na trajetória viva da pesquisadora}

Marcia Longhi: Também pensando um pouco naquela sua entrevista, acho que o que você disse na época se liga muito com o que está falando agora, sobre estudar os campos para cima e como isso se conecta com uma discussão ética. Fiquei curiosa para ouvir um pouquinho mais.

Claudia Fonseca: Bueno. O problema foi que, por força de trabalhar sempre com grupos populares, nós (eu e muitos dos meus estudantes) acabamos sendo convidados a entrar em parcerias com serviços públicos e organizações não governamentais (ONGs) em atividades que visavam à promoção de direitos (da mulher, da saúde, de cidadania etc.). Mas tinha uma tendência, da parte dos gestores desses programas, em ver o antropólogo como alguém que ia tornar os "costumes nativos" inteligíveis para eles. Era para a gente decodificar a "cultura" dos pobres, dos indígenas, dos "exóticos", para os especialistas poderem realizar uma intervenção mais eficaz. Em outras palavras, era aquela velha ideia do antropólogo como...

\section{Marcia Longhi: Tradutor...}

Sim, e numa relação de mão única. A ideia, em geral, era encontrar uma maneira de facilitar a comunicação, visando alcançar os objetivos do programa e não para readequar o desenho do programa (incluindo os objetivos) em função das demandas. Aliás, se houvesse uma verdadeira conversa de dupla mão, quem teria maior competência para dar assessoria seriam os próprios "clientes" (organizados ou não em grupos). Assim, a certa altura, passou a ser uma opção política mudar a mira de nossas atenções, passando agora a estudar etnograficamente os espaços de poder. Esmiuçar a complexidade desses espaços - os diferentes atores e as lógicas heterogêneas - parecia ser uma maneira de contribuir para a reformulação ou, no mínimo, para a flexibilização dos próprios programas de intervenção.

Cabe acrescentar que a crítica pós-colonialista nos obrigou a repensar a maneira como nós antropólogos criávamos a categoria de "outro" - a maneira e as consequências. A guinada reflexiva do movimento pós-colonialista levou os antropólogos a virar a lente analítica para a própria disciplina - as condições dessa produção de conhecimento. Quando passamos a refletir sobre nossas próprias práticas, já estávamos estudando "para cima”.

Em todo caso, não inovei em nada. Já havia muitos antropólogos, inclusive brasileiros, estudando as instâncias de poder antes de mim. Começamos a usar esse termo "studying up" a partir de Laura Nader, que veio palestrar na Rede Brasileira de Antropologia (RBA) - acho que foi em 1996. Patrice Schuch foi fazer seu doutoradosanduíche com Laura, no início dos aos 2000, e trouxe o termo de volta para o 
Núcleo de Antropologia e Cidadania (NACI). A partir desse momento se tornou rotina incluir nas nossas observações de qualquer atividade de intervenção tanto os profissionais quanto os "usuários" do sistema - sem esquecer, é claro, a presença e impacto do próprio pesquisador. E virou hábito: a necessidade de descrever tanto o juiz quanto o infrator sendo julgado; tanto o psicólogo quanto a mãe recebendo terapia; tanto o médico quanto o paciente sendo atendido; tanto os legisladores em Brasília quanto os funcionários "locais" que estão tentando implementar o programa social etc. E de lá, foi um curto passo para começar a estudar os próprios conhecimentos (as "ciências") que deviam informar a prática dos profissionais e os sistemas administrativos que mediavam toda a atividade.

Quanto mais pesquisávamos os diferentes serviços e instituições, mais ficávamos convencidos de que os próprios arranjos administrativos explicavam o que estava acontecendo lá dentro, tanto, senão mais, do que qualquer "atitude cultural" dos atores. Isso se tornou evidente já na pesquisa que fizemos sobre a Febem. Parecia que certas mudanças administrativas, mesmo respeitando os princípios do ECA, tinham criado uma nova situação extremamente volátil (FONSECA; CARDARELLO, 1999). Para nós, ficou claro que a própria estrutura administrativa tinha uma força incrível.

Comecei a pensar, como antropóloga, será que esses aspectos administrativos e burocráticos não estão me escapando? Esse negócio de estudar para cima não é só estudar a prática dos especialistas (incluindo, é claro, os antropólogos) - as suas atitudes, as suas perspectivas, as suas certezas que trazem para determinada situação. Essa é uma das coisas. Mas uma outra coisa é pensar o sistema e suas mediações elementos chatos e rotineiros da regulamentação administrativa. Aí entra o tema "tecnologias de governo" - claro, com resquícios de Foucault, mas com ênfase nos mediadores e nas mediações sempre imprevisíveis.

Trazendo um exemplo mais recente, posso citar um estudo que realizei junto com uma pós-doutoranda, Lucia Scalco, sobre o desenrolar do Programa Fome Zero, em Porto Alegre. Nosso alvo inicial era entender como a comida distribuída estava sendo incorporada no cotidiano das pessoas - mudando relações sociais além de regimes alimentares. Mas, por força de nos envolvermos na organização política local, fomos sendo convencidos de que mudanças administrativas do Programa introduzidas em nível nacional para combater a corrupção - estavam provocando sérios problemas. A exigência de documentação cada vez mais complicada (como CNPJ) arriscava expulsar muitas organizações comunitárias da rede. Formalidades administrativas provocavam atrasos no estabelecimento de convênios com produtores agrícolas locais, criando longos períodos em que simplesmente não havia produto para distribuir. Gupta, no seu livro Red Tape (2012), traz exemplo semelhante abordando projetos sociais na Índia. Ele chega à conclusão de que, apesar das melhores intenções, muitas vezes os impedimentos burocráticos tornam os projetos sociais totalmente ineficazes. 
Minha experiência com o Fome Zero me levou a outro campo de indagação, que ainda tem a ver com ciência e tecnologia: o estudo da infraestrutura. Sempre vão existir dificuldades em um programa de distribuição de alimentos, muitas das quais são de ordem logística. De fato, enquanto os políticos estavam preocupados com grandes princípios, era com esse tipo de detalhe - miúdo e aparentemente insignificante - que as lideranças comunitárias envolvidas no Programa mais se preocupavam. Como garantir transporte em caminhões refrigerados que preservariam a qualidade dos produtos? Onde conseguir espaço para armazenar, nem que fosse por algumas horas, as entregas de alimentos? Como encontrar sacos de plástico para realizar a distribuição para a vizinhança? Como avisar os recipientes da chegada dos alimentos? Suas perguntas tinham tudo a ver com mediações $e$ materialidades tão centrais nas análises de ciência e tecnologia. Aí, olhar para esses problemas de infraestrutura - essas mediações do sistema que, muitas vezes, são ignoradas, tratadas como coisas meramente técnicas - passou a sugerir um novo caminho para mim.

Pedro Nascimento: Você já falou um pouco sobre isso, Claudia, mas - sem querer personalizar demais, tua entrada nesse campo dos estudos de ciência e tecnologia, no seu trabalho sobre o DNA - você percebe uma especificidade, dá para falar assim, de uma mudança ou mais como uma continuidade na tua trajetória de pesquisa. Haveria algo de mais específico do lugar do antropólogo para pensar seu papel nesse campo dos estudos da ciência?

Claudia Fonseca: Há muitas maneiras de responder tua pergunta. Cabe lembrar que minha trajetória não é muito diferente da de muitos outros pesquisadores feministas que estudavam família e parentesco. A desnaturalização da família e do gênero levou logicamente à desconstrução das noções científicas que, de forma tão persuasiva, tinham definido esses conceitos. Estudar as práticas da ciência nos ajudou a entender como chegávamos (e chegamos ainda) a certezas tão firmes a partir de processos tão frágeis e contingentes.

Mas confesso que meu interesse em ciências sociais surgiu apenas no meu segundo ano de faculdade, quando estava em Bordeaux (França), e fiz uma cadeira com Jacques Ellul, autor de La technique, l'enjeu du siècle. Para mim, era fascinante a maneira com que ele mostrava como uma certa lógica, a da eficácia - materializada em novas máquinas, modos de organização, e hábitos cotidianos -, estava fazendo transformações radicais na vida moderna. Era tudo grande plano, meio determinista, como os sociólogos daquela época faziam. Depois disso, felizmente fui desviada pela antropologia, com sua abordagem mais concreta e contextualizada de pensar as coisas. Mas, quando Latour chegou em cena, era como se eu estivesse encontrando um método que pudesse dar um caráter dinâmico, contextualizado e nada determinista a algumas daquelas ideias que tinham me encantado na década de 1960.

Em todo caso, estamos sempre mudando em função das peripécias de nossas trajetórias pessoais. Para mim, minhas escolhas teóricas e de pesquisa não são 
planejadas; são o resultado de encontros inesperados. É como o campo, que traz coisas novas e muitas vezes te obriga a mudar de direção. Lembro que entrei no tema de DNA porque tive que escrever um artigo para a Fundação Carlos Chagas sobre a família brasileira. Pensei: como posso dizer algo novo - que eu ou algum colega não tenha já discutido vinte vezes? Naquela época, estava conversando com uma amiga que trabalhava no Juizado, nas Varas de Família. Sempre ficava fascinada com os casos que ela me descrevia. Um desses casos - de uma menina que tinha que fazer um teste de DNA para averiguar a maternidade - acabou sendo mote do meu primeiro artigo sobre esse tema: "A vingança de Capitu" (FONSECA, 2002a). A partir desse encontro, fui descobrir quantos outros pesquisadores da família especialmente na linha de estudos feministas - tinham voltado seu olhar para a ciência e as novas tecnologias. Um novo universo se abriu diante dos meus olhos.

Mas, é claro, uma coisa é estudar o impacto das novas tecnologias na vida das pessoas, outra coisa é estudar os cientistas e produtores dessas tecnologias. Confesso que não tem sido tão simples para mim. Tinha trabalhado durante boa parte de minha carreira curtindo a ideia de Bourdieu da "sociologia como esporte de combate". Era muito fácil para mim adotar um argumento adversarial e, em geral, as pessoas, sistemas ou ideias de cima da hierarquia sociopolítica ocupavam o lugar de adversário. Naquele capítulo de Reassembling the social, "The fortunate wreck of the sociology of science", Latour (2005) nos cutuca sobre esse tipo de atitude. Ele mesmo tinha passado por momentos nada confortáveis no debate com seus "sujeitos de pesquisa" e tinha chegado à conclusão de que pouco importa se é cientista no seu laboratório ou trobriandês na sua oca. A partir do momento em que alguém se torna interlocutor de pesquisa, a gente lhe deve a mesma escuta atenciosa, o mesmo respeito questionador. Isso não significa que nossos interlocutores têm que endossar com entusiasmo todas as nossas análises, mas temos que ser responsáveis: escutar críticas e manter o diálogo aberto.

Agora, esse artigo que acabo de apresentar na reunião na $\mathrm{ABA}$ é de certa forma fruto desse processo (FONSECA; GARRIDO, 2016). Começou por causa da pesquisa de Vitor [Richter] sobre o banco de perfis genéticos para perseguição criminal (RICHTER, 2016). Eu já tinha escrito sobre esse tema, mas ficando sempre a uma certa distância do mundo da perícia. Minha preocupação era com as possíveis violações dos direitos humanos. Já que no início conhecíamos só os peritos que apoiavam energicamente o banco, tendíamos a vê-los quase como adversários. O problema é que esta não é uma atitude que vá abrir portas para fazer pesquisa junto aos cientistas e seus laboratórios. E, não por acaso, encontramos muitas portas fechadas. Vitor tinha dificuldade em encontrar um lugar onde pudesse entrar e estudar "para cima", trabalhar junto com os próprios peritos. (Ironicamente, um outro estudante, Lucas Besen, foi recebido sem dificuldade, pela mesma polícia federal, para estudar perícias químicas de drogas. Mas temos que lembrar que, naquele momento, o banco de perfis genéticos estava em vias de ser institucionalizado por meio de lei congressional e o assunto era controvertido.) 
Sabíamos que a pesquisa de Vitor ia ficar meio capenga se ele não conseguisse se aproximar etnograficamente da prática dos peritos. Parecia difícil, mas estávamos determinados a encontrar uma pessoa mediadora na administração do próprio laboratório que estivesse, por um motivo ou outro, aberta à pesquisa. E nós encontramos, ops!, nós não, Victor encontrou Rodrigo Garrido - esse diretor de laboratório genial, no Rio de Janeiro, uma pessoa que cumpre com extrema dedicação o trabalho de perícia genética, mas que não deixa de pensar criticamente. Ele acabou sendo não só uma porta de acesso aos dados, mas também uma fonte incrível de ideias analíticas. Eu estava curiosa para ver o que nós - duas pessoas de áreas muito diferentes - podíamos fazer juntos, questionando, pensando, provocando, e ele teve coragem de fazer isso junto comigo. Daí que vieram esses artigos em coautoria.

Depois, não vou nem entrar muito nisso porque não temos tempo, mas devo pelo menos mencionar a pareceria que fizemos (eu e a doutoranda Glaucia Maricato) com a Genética da UFRGS - via a Profa. Lavínia Schuler-Faccini - para trabalhar com o tema de Hanseníase. Lavínia é médica e geneticista, mas também tem total simpatia pelas ciências sociais. Ela estabeleceu o tom de nossos primeiros encontros no campo, incorporando-nos como aliadas no ativismo junto ao movimento social, o Movimento de Reintegração das Pessoas Atingidas pela Hanseníase (Morhan). Ela, inspirada pelas Abuelas de la Plaza de Mayo, já estava fazendo coleta de DNA entre os "filhos 'separados" de pacientes compulsoriamente internados (até 1986) - justamente para propiciar o reencontro entre familiares. E ela nos abriu todas as portas para desenvolver novas facetas da pesquisa de equipe já em andamento. De novo, entre muitos momentos de intercâmbio, acabamos sendo coautoras, junto com nossas doutorandas, numa consideração ética sobre o Projeto Reencontro (FONSECA et al., 2015).

Mais uma vez, não estou vendendo uma receita, porque acho que tem lugar na antropologia para uma diversidade de posturas, para diferentes tipos de texto, atuação e estilo de crítica. Mas penso que, para mim, nesse momento na minha carreira, a ideia da colaboração está me levando para desafios interessantes.

Flávia Pires: Mas Claudia, tenho colegas da história, do serviço social que descobrem seus textos e vem conversar comigo, e eu digo: Ah! É a Claudia Fonseca. Aquele texto "Mãe não é uma só" (FONSECA, 2002b), repercutiu muito fora da antropologia.

Claudia Fonseca: Ah, que legal, mas eu quero saber o que vocês estão fazendo?

Marcia Longhi: A gente tem que passar um dia junto.

Flávia Pires: Vem pra cá um semestre.

Marcia Longhi: Seria maravilhoso. 
Claudia Fonseca: Seria sim. Vamos pensando. Eu quero escutar três minutos de cada um de vocês, o que vocês estão produzindo. Me desculpem, porque eu falo muito.

Flávia Pires: Obrigada.

Pedro Nascimento: Muito obrigada, Claudia

Marcia Longhi: Muito obrigada, Claudia. Saímos revigorados.

\section{Referências}

BELLACASA, Maria Puig de la. Matters of care in technoscience: Assembling neglected things. Social Studies of Science, v. 41, n. 1, p. 85-106, 2011.

FASSIN, Didier. Introduction: Toward a Critical Moral Anthropology Moral Anthropology. In: FASSIN, Didier (org.). A companion to Moral Anthropology. Oxford: Wiley-Blackwell, 2012.

. Why ethnography matters: Anthropology and its publics. Cultural Anthropology, v. 28, n. 4, p. 621-646, 2013.

FONSECA, Claudia. A vingança de Capitu: DNA, escolha e destino na família brasileira contemporânea. In: BRUSCHINI, Cristina; UNBEHAUN, Sandra (org.). Gênero, Democracia e Sociedade Brasileira. São Paulo: Ed. 34, 2002a.

. Mãe é Uma Só?: Reflexões em Torno de Alguns Casos Brasileiros. Psicologia USP, São Paulo, v. 13, n. 2, p 49-68, 2002b. Disponível em: <http://www.scielo.br/scielo.php?script=sci_arttext\&pid=S010365642002000200005\&lng=en\&nrm=iso $>$. Acesso em: 30 out. 2017.

Feminismos e estudos feministas: com as trabalhadoras sexuais na mira. Cadernos Pagu, Campinas, n. 47, e16473, 2016. Disponível em: <http://www.scielo.br/scielo.php?pid=S010483332016000200303\&script=sci_abstract\&tlng=pt $>$. Acesso em: 17 mar. 2017.

FONSECA, Claudia; CARDARELlO, Andrea. Direitos dos mais e menos humanos. Horizontes Antropológicos, Porto Alegre, ano 5, n.10, p. 83-122, 1999.

FONSECA, Claudia; SCHUCH, Patrice (orgs.). Políticas de proteção à infância: um olhar antropológico. Porto Alegre: Ed. da UFRGS, 2009.

FONSECA, Claudia; BIONDI, Flávia Costa; MARICATO, Glaucia Cristina; SCHULER-FACCINI, Lavínia. Project REENCONTRO: ethical aspects of genetic identification in families separated by the compulsory isolation of leprosy patients in Brazil. Journal of Community Genetics, v. 6, n. 3, p. 215-222, jul. 2015.

FONSECA, Claudia; GARRIDO, Rodrigo. Os limites do 'humano': O agency (e complicações) de restos humanos em um laboratório de genética forense. In: REUNIÃO BRASILEIRA DE ANTROPOlOGIA, 30. Anais..., João Pessoa, 2016. Disponível em: <http://www.abant. org.br/conteudo/ANAIS/30rba/admin/files/1467631915_ARQUIVO_ Limitesdohumanofonsecaegarrido.pdf $>$.

FOUCAULT, Michel. Histoire de la sexualité: L’usage des plaisirs. Vol. 2. Paris: Gallimard, 1984.

GUPTA, Akhil. Red Tape: Bureaucracy, Structural Violence, and Poverty in India. Durham, NC: Duke University Press, 2012.

LATOUR, Bruno. Reassembling the social: an introduction to actor-network theory. Oxford: Oxford University Press, 2005. 
RICHTER, Vitor Simonis. Identificação genética e crime: a introdução dos bancos de DNA no Brasil. 2016. Tese (Doutorado em Antropologia Social) - Universidade Federal do Rio Grande do Sul, Porto Alegre, 2016.

RUBIN, Gayle; BUTLER, Judith. Tráfico sexual: entrevista. Cadernos Pagu, Campinas, n. 21, p. 157-209, 2003. Disponível em: <http://www.scielo.br/scielo.php?script=sci_arttext\&pid=S0104$83332003000200008 \& \operatorname{lng}=e n \& n r m=i s o>$. Acesso em: 30 out. 2017.

STRATHERN, Marilyn. Dear David.... Cultural Anthropology, v. 12, n. 2, p. 281-282, 1997.

Recebido em 15/06/2017

Aceito em 19/07/2017 